O. TOMASZ GAŁKOWSKI C.P.

Uniwersytet Kardynała Stefana Wyszyńskiego w Warszawie

\title{
TEOLOGIA PRAWA
}

Treść: -1 . Prawo a sfera sacrum. -2 . Teologiczny problem prawa. -3 . Teologiczne zainteresowania prawem. -4 . Protestancka teologia prawa. -5 . Katolicka teologia prawa.

W ubiegłym stuleciu pojawiły się w badaniach dotyczących zjawiska prawnego analizy teologiczne. Nie jest to jedynie sytuacja odnosząca się do prawa kanonicznego, lecz ogólnie do zjawiska prawa, które stało się przedmiotem badań teologalnych. Do tego rodzaju działalności naukowej przylgnęła nazwa teologii prawa. Na pytanie dotyczące określenia tego, czym jest ta nowa dyscyplina naukowa, będę starał się odpowiedzieć w toku niniejszych rozważań.

\section{Prawo a sfera sacrum}

W badaniach nad początkami zjawiska prawnego dostrzega się jego powiązanie ze sferą sacrum, w której można się doszukiwać pierwotnych, a jednocześnie bardzo wyrazistych oznak działalności normatywnej. Wraz z ustaleniem miejsca dla sacrum tworzone reguły postępowania miały to miejsce zabezpieczać jako punkt odniesienia tego, co dla człowieka niepokonalne i niezrozumiałe z pierwotnego chaosu. Jednocześnie to, co pochodziło od sacrum było dla człowieka ważne i obowiązujące, efektywne i skuteczne, zawierając w sobie treści świadczące o sensowności wykraczającej poza zbiorowe stanowienia i będące dla nich niezaprzeczalnym punktem odniesienia. Jednocześnie reguły wywodzące się ze sfery sacrum posiadały charakter generalności i abstrakcyjności w przeciwieństwie do konkretnych i indywidualnych reguł współżycia społecznego stanowionych przez człowieka. 
Stąd też niewyobrażalną rzeczą było nieprzestrzeganie owego świętego porządku. Obowiązek zachowania, mający swe źródło w porządku panującym w sferze sacrum, nie wynikał jednak ze strachu przed bóstwem, lecz z faktu koniecznościowej przynależności do owego porządku. ${ }^{1}$ Prawo, oddzielając świat człowieka od reszty świata, jednocześnie było wyrazicielem przekonania i ludzkich potrzeb, skłaniających do uznania pewnego ładu (kosmosu), by w ten sposób uzasadnić i usprawiedliwić w nim obecność samego człowieka. Odniesienie ludzkiego życia do porządku i ładu panującego w sferze sacrum miało na celu ukazanie prawzoru wszelkich relacji międzyludzkich.

Od najstarszych czasów myślenia o prawie obserwujemy zatem silne odniesienia praw stanowionych przez czlowieka do pewnej i stałej idei ładu i porządku wykraczających poza reguły czysto ludzkie. Prawo pochodzące od bóstw było jednocześnie punktem odniesienia dla praw stanowionych przez człowieka, a prawa stanowione wbrew prawom boskim nie tylko były prawami niesprawiedliwymi, ale nie były prawem w ogóle i nie posiadały mocy zobowiązującej.

Prawo stanowione przez człowieka było poddawane ocenom w świetle prawa mającego boską proweniencję. Dokonywano oceny prawa porównując jego pozytywne rozwiązania z regułami o charakterze naturalnym, których istnienie odnoszono do pozaludzkich źródeł czy bezpośrednio do wskazań prawa Bożego, które wyinterpretowywano $\mathrm{z}$ faktów Objawienia. Treść prawa stanowionego stawała się tym samym punktem zainteresowania teologii. Teologia interesowała się prawem, ale tylko $\mathrm{w}$ jego jednym aspekcie: zgodności lub nie pozytywnych postanowień prawa $\mathrm{z}$ naturalnym prawem moralnym (lex moralis naturalis), czy pozytywnym prawem Bożym. Teologiczne zainteresowania prawem stanowionym dotyczyły zatem jego wymiaru moralnego czy etycznego. Prawo tym samym stawało się przedmiotem ocen moralnych dokonywanych w ramach teologii moralnej.

${ }^{1}$ Por. G. Cosi, Il Logos del diritto, Torino 1993, ss. 61-143. Tenże, Naturalità del diritto e universali giuridici, Rivista internazionale di filosofia del diritto 71(1994) 2, ss. 216-242. 
Zainteresowania prawem z punktu widzenia teologii moralnej zaczęły tracić na znaczeniu wraz z pojawieniem się protestantyzmu, który deprecjonował znaczenie i przydatność prawa w perspektywie zbawienia oraz wraz z pojawieniem się racjonalistycznej szkoły prawa (H. Grocjusz), w ujęciu której prawo i moralność stanowiły dwie rzeczywistości autonomiczne. Apogeum rozejścia się teologicznych zainteresowań prawem nastąpiło wraz z osobą Ch. Thomasiusa, a następnie H. Kelsena, którzy twierdzili, że prawo i moralność różnią się między sobą istotowo i funkcjonalnie i dlatego całkowicie są od siebie oddzielone. Pomiędzy prawem i moralnością nie ma żadnych wspólnych obszarów (dla S. Puffendorfa i I. Kanta prawo i moralność nie są identyczne ani całkowicie oddzielone, stąd istnieją pomiędzy nimi pewne obszary wspólne), prawo pozostaje pod wpływem ocen z zakresu prawa, a moralność podlega ocenom tylko w kategoriach moralnych. ${ }^{2}$

\section{Teologiczny problem prawa}

Przedstawiony powyżej historyczny proces teologicznego podejścia do prawa wskazywał, iż koncentrowało się ono głównie wokół problematyki zgodności norm prawa stanowionego przez człowieka $\mathrm{z}$ naturalnym prawem moralnym i w zasadzie różne teorie prawa naturalnego $\mathrm{w}$ konsekwencji stanowily epistemologiczne odniesienie dla rozważań wokół prawa. Problematyka z zakresu teologii wkraczała w zakres odniesień filozoficznych tracąc tym samym sprzed oczu to, co dla teologii prawa powinno być najistotniejsze, a mianowicie specyficzny teologalny, eklezjologiczny ogląd rzeczywistości jaką jest prawo, jako jeden z elementów życia człowieka na jego drodze zmierzającej ku zbawieniu. By teologia prawa mogła pozostać dyscypliną teologiczną musi w całym swym kształcie zachować to, co jest podstawą jej istnienia, jej eklezjalny charakter poprzez nieustanne odniesienie do swego źródła jakim jest Boże Objawienie. Tym samym teologia prawa będzie w stanie zachować swoje epistemologiczne znaczenie

2 Por. A. Kość, Relacja prawa i moralności we współczesnej filozofii prawa, Roczniki Nauk Prawnych 11(2001)1, ss. 23-34. 
jako jedna z form ludzkiego poznania, poszerzająca czy dopełniająca inne jego formy. ${ }^{3}$

Konfrontacja treści stanowionych przez człowieka norm z normami naturalnego prawa moralnego wskazuje zatem, że nie jest to właściwy problem teologii prawa. Obiektem zainteresowań teologii prawa nie jest prawo w znaczeniu normy (lex), lecz prawo w znaczeniu intersubiektywnej i kategorialnej relacji powinnościowej, jaka istnieje pomiędzy ludźmi, która w konsekwencji przyjmuje formę znormatywizowaną. Normatywność może przybrać charakter albo moralny albo prawny. Ten drugi aspekt staje się przedmiotem teologii prawa. Punktem wyjścia jest zatem sama relacja, a właściwie osoby, które tę relację tworzą. Zainteresowania teologiczno-prawne powinny zatem koncentrować się wokół samego człowieka, który tworzy relację powinnościową i wypełnia ją treścią. Teologia prawa wskazuje na podstawy zjawiska prawnego mówiąc w świetle Objawienia o tym, który jest autorem relacji prawnej. Tym samym teologia prawa mówi także o samym prawie w świetle Objawienia, nakreślając jego teologalne podstawy. Gdyby teologia prawa koncentrowała się jedynie wokół aspektu treściowego relacji prawnej (norma), czy też chciałaby go uprzywilejować w stosunku do samej relacji międzyosobowej uczyniłaby z prawa rzeczywistość statyczną, ujmowaną przez człowieka jako pewna forma jednoznacznego sposobu istnienia i działania.

Teologia natomiast jako nauka, która wsłuchuje się w historycznie objawione autentyczne słowo Boże zmierza do jego poznania. Teologia w punkcie wyjścia przyjmuje należyte słuchanie słowa Bożego, którego zrozumienie i przyjęcie ma służyć zbawieniu. ${ }^{4}$ Punktem wyjścia teologii jest słowo objawiającego się i mówiącego do człowieka Boga. Teologia będzie w stanie zachować swoją specyfikę poznawczą, a przy tym także epistemologiczne odniesienie dla teologii prawa, o ile słowo Boże nie będzie stanowiło jedynie skostniałego przekazu,

3 Por. F. D’Agostino, La teologia del Diritto positivo: Annunzio Cristiano e Verità del Diritto, w: "Evangelium vitae" e diritto. Acta Symposii internationalis in civitate Vaticana celebrati 23-25 maii 1996, Libreria editrice Vaticana 1997, s. 123.

${ }^{4}$ Por. Teologia, w: K. Rahner, H. Vorglimler, Mały słownik teologiczny, Warszawa 1987, kol. 466. 
lecz będzie traktowane przez nią jako nieustanna obietnica skierowana w historycznym momencie do konkretnych ludzi. Słowo Boże musi pozostać jako dobra nowina, jako obietnica, która będzie wzbudzała nadzieję, oraz dawała moc w postępowaniu ku wyznaczonym celom. Dynamiczne ujęcie słowa Bożego posiada swoje znaczenie również dla rozważań w ramach teologii prawa. Prawo Boże (lex) w takim podejściu nie będzie rozumiane jedynie jako jednoznaczna wola Boża raz na zawsze wypowiedziana, lecz jako dynamiczna obietnica, która dąży do swego wypełnienia. ${ }^{5}$

Teologia prawa staje zatem wobec człowieka zanurzonego w relację prawną. Wsłuchując się nieustannie w słowa mówiącego i objawiającego się Boga stroni od niewłaściwych paradygmatów czy też konkretnych i niezmiennych rozwiązań. Obiektem odniesienia dla teologii prawa nie jest jakaś idea prawa, lecz człowiek w jego pełnym obrazie tak, jak odczytujemy to z Objawienia. Teologia prawa wskazując na właściwy podmiot relacji prawnej będzie analizowała i wskazywała jego możliwości życia we wspólnocie, której możliwości wyrastają poza ramy wyznaczone ludzką pomysłowością. Teologia prawa odgrywa swoje podstawowe znaczenie na płaszczyźnie epistemologicznej poznając człowieka żyjącego sub specie iuris. W tym sensie teologia prawa ma do odegrania dużą rolę w kontekście kulturowym i prawnym jako specyficzna kategoria hermeneutyczna w poznaniu i rozumieniu relacji prawnej. Teologia prawa może nadać prawu nowe horyzonty jego istnienia i ukazać mu nowy sens. Jej zadaniem nie jest wypełnianie prawa teologicznymi treściami, lecz wskazanie mu rzeczywistości odczytanych w innej formie poznania. Teologia prawa może stać się poznawczą propozycją oraz inspiracją dla stanowionego prawa.

5 Przykładem takiego ujęcia prawa Bożego są na gruncie prawa kanonicznego sytuacje, w których udzielana jest dyspensa od prawa Bożego. Dyspensa w tym momencie jest doskonalszą formą zachowania prawa Bożego w odniesieniu do konkretnej osoby znajdującej się w indywidualnej sytuacji. Inna forma zachowania prawa Bożego staje się w ten sposób pewniejszym środkiem osiągnięcia zbawienia na drodze indywidualnego powołania. 


\section{Teologiczne zainteresowania prawem}

Początków teologii prawa, jak twierdzi P. Gherri ${ }^{6}$, należy poszukiwać w sytuacji, w jakiej znalazły się kościoły protestanckie w Niemczech po dojściu do władzy A. Hitlera. Do tego momentu sytuacja Kościołów protestanckich była unormowana przez cesarza Fryderyka Wilhelma III, który stworzył w 1817 r. tzw. Unię Ewangelicką, w skład której wchodziły Kościoły luterańskie, kalwińskie i reformowane $\mathrm{w}$ ramach jednego Kościoła narodowego. Po dojściu do władzy Hitlera w ramach Kościoła narodowego pojawiły się odłamy będące zwolennikami ideologii nazistowskiej. Powstały w 1932 r. ruch niemieckich chrześcijan (Deutsche Christen), dążył do utworzenia w Niemczech centralistycznego Kościoła niemieckiego (Reichskirche). Sprzyjała temu ideologia nacjonalistyczna. Ostatecznie działania niemieckich chrześcijan doprowadziły do powstania sympatyzującego z ideologią nazistowską centralistycznego Kościoła niemieckiego na czele z oficjalnym biskupem Rzeszy (Ludwig Müller). Kościół ten, przyjmując obcą chrześcijaństwu ideologię nazistowską wraz z zasadą wodzostwa (Führerprinzip), dostrzegał w nacjonalistycznej rewolucji miejsce i czas objawienia się Boga, którego rzecznikiem miał być A. Hitler. ${ }^{7}$ Podczas pierwszego synodu nowo utworzonego narodowego Niemieckiego Kościoła Ewangelickiego (Deutsche Evangelische Kirche) we wrześniu 1933 r. przyjęto tzw. paragraf aryjski, który, zgodnie z ideologią nazistowską, zabraniał wszystkim, którzy nie są przedstawicielami czystej rasy aryjskiej, przyjmowania urzędów szafarzy kościelnych oraz nauczania religii. ${ }^{8}$ Kościół narodowy podporządkował się całkowicie prawom stanowionym przez państwo w sprawach religijnych. Nie była to sytuacja nowa dla Kościołów protestanckich, gdyż pozostawiały one kompetencje legislacyjne państwu w odniesieniu do

${ }^{6}$ Por. P. GHeri, Primi appunti per una storia delle origini della Teologia del Diritto (canonico), Ius Canonicum 50(2010), s. 226.

${ }^{7}$ Por. P. Circa, Chiesa confessante, w: Enciclopedia del cristianesimo, Navarra 1997, s. 156.

8 Por. P. GHeriI, Primi appunti per una storia delle orogini della Teologia del Diritto (canonico), s. 224. 
swoich spraw wewnętrznych. Nowa sytuacja przyczyniła się jednak do postawienia konkretnego pytania dotyczącego natury samego państwa etycznego oraz natury prawa, których postanowienia znajdują się w całkowitej niezgodzie z wiarą chrześcijańską.

Obrony, wobec zagrożeń ideologii nazistowskiej, autonomii Kościoła Ewangelickiego podjęła się organizacja tzw. Tymczasowego Związku Proboszczów (Pfarrernotbund) założona przez M. Niemöllera, który zadeklarował niekompatybilność praw rasowych z wiarą chrześcijańską. Silny ruch odśrodkowy w ramach niemieckiego Kościoła Ewangelickiego, wspierany przez D. Bonhoeffera i K. Bartha, który ostatecznie przejął w nim kierownictwo teologiczne, przyczynił się w 1934 r. do powstania, w opozycji do Kościoła niemieckich chrześcijan, tzw. Społeczności Wyznaniowej Niemieckiego Kościoła Ewangelickiego czyli Kościoła wyznaniowego (Bekenntnisgemeinschaft). Kościół ten odrzucił jakiekolwiek podporządkowanie się władzom państwowym, zwierzchnictwo osób narzuconych z zewnątrz czy ograniczenie swobody głoszenia słowa Bożego zgodnie z wyznawaną wiarą. ${ }^{9}$

Pierwszy synod Kościoła wyznaniowego, mający miejsce w Barmen w dniach 29-31 maja 1934 uważany jest również za formalny moment powstania Teologii prawa. Deklaracja teologiczna z Barmen (Barmer theologische Erklärung), zredagowana głównie przez K. Bartha i H. Asmussena, była wyrazem wiary luteran i ewangelików reformowanych przeciw twierdzeniom grupy niemieckich chrześcijan. Jednocześnie stanowiła i wyraźnie wskazywała teologiczne podstawy Kościoła wyznaniowego w czasach nazistowskiego reżimu. Deklaracja była w swojej treści zorientowana chrystocentrycznie (zasługa K. Bartha). Podkreślała centralne miejsce Chrystusa jako fundamentu wiary Kościoła, odrzucając tym samym wszelkie zewnętrzne i sprzeczne z wiarą chrześcijańską próby jej wykorzystania dla politycznych celów reżimu nazistowskiego przeciwnych ewangelicznemu przesłaniu. W Deklaracji uwypuklono, że Chrystus jest nieustannie obecny

9 Por. Z. ZIELIŃSKI, Bekennende Kirche, w: Encyklopedia Katolicka, Lublin 1989, t. 2, koll. 187-188. 
w chrześcijańskich gminach dając wierzącym życie łaski przez posługę duchową, a nie, wbrew Führerprinzip, przez obecność ministrów sprawujących władzę w Kościele. Deklaracja uznała rolę państwa jako niezbędnego organizmu dla utrzymania porządku, ale całkowicie sprzeciwiła się jego działaniu, które nie respektuje ewangelicznych zasad sprawiedliwości. ${ }^{10}$

Przemiany dokonane wewnątrz Kościoła niemieckiego miały swoje znaczenie nie tylko na poziomie społeczno-politycznym, ale przyczyniły się do zmian w myśleniu teologicznym. To, co zostało proklamowane w Deklaracji z Barmen zachwiało dotychczasowym porządkiem istniejącym w Kościołach protestanckich. Niemiecki Kościół wyznaniowy zerwał z dotychczasowym wpływem państwa na obsadzanie stanowisk kościelnych, a w tym przede wszystkim na obsadzanie urzędu biskupa. Państwo przestało tym samym pełnić rolę opiekuńczą w stosunku do Kościoła, a co za tym idzie przestało pełnić swoją dotychczasową funkcję prawodawczą, która od tej pory miała stać się jedyną kompetencją Kościołów protestanckich.

Punktem wyjścia kształtującej się Teologii prawa była kwestia dotycząca samego prawa. Kościół wyznaniowy nie był w stanie zaakceptować prawa państwowego w wydaniu ideologii nazistowskiej. Sytuacja ta zrodziła pytania dotyczące tego, jakim prawem powinno się kierować państwo. Pytanie dotyczyło zatem prawa jako takiego. Odpowiedzi nie można było poszukiwać w epistemologicznych zakresach, które doprowadziły w konsekwencji do prawa nazistowskiego, a więc w oparciu o doktrynę kantowską, czy idealizm heglowski, a w ostateczności o kelsenowski normatywizm, dalekich chociażby od oświeceniowych i racjonalistycznych założeń prawnonaturalnych. Do sytuacji, w której jedyne predyspozycje prawodawcze znajdowały się w rękach państwa przyczyniły się teologiczne dywagacje R. Sohma, doradcy O. von Bismarcka, który głosił tezę, że duchowa natura Kościóa i prawo są rzeczywistościami tak sobie przeciwstawnymi, że niemożliwe jest, by Kościół posiadał jakiekolwiek własne prawo. Zewnętrzne formy działalności Kościoła pozostają zatem w gestii sa-

${ }^{10}$ Por. tamże, kol. 188. 
mego państwa. W oparciu o silną państwową ideologię germańską, wspieraną przez teologię protestancką, przekonanie państwa o jedynie jemu przysługujących kompetencjach prawodawczych w odniesieniu do wszystkiego, co na jego terenie istnieje doprowadziło w ostateczności do ujmowania prawa i jego stanowienia w taki sposób, który odpowiadałby aktualnym potrzebom państwa. Kościół wyznaniowy nie godząc się $\mathrm{z}$ ingerencją państwa w jego sprawy wewnętrzne wraz z narzucaną i sprzeczną z wiarą chrześcijańską ideologią nazistowską postawił zatem pytanie dotyczące natury samego prawa oraz państwa etycznego. Problem prawa nie był zatem problemem społeczno-politycznym, ale stał się tym samym problemem ontologicznym.

Dostrzegając tym samym, że dotychczasowe formy uzasadnienia prawa doprowadziły do sytuacji, w której nie można go zaakceptować w ramach Kościoła wyznaniowego, jego przedstawiciele postawili kolejny problem, tym razem epistemologiczny, dotyczący sposobu określenia tego, czym prawo jest. $Z$ jednej strony próba odpowiedzi na pytanie dotyczące samego prawa pozostawała w zgodzie z tradycją protestancką. Nie jest to kompetencją Kościoła, lecz pozostaje kwestią filozoficzną. Z drugiej jednak strony filozoficzne rozważania dotyczące prawa doprowadziły ostatecznie do schizmy w Kościele niemieckim i w ostateczności do ustawienia się Kościoła wyznaniowego w opozycji do państwa. W takiej sytuacji uprawnioną drogą poszukiwania podstawowych odpowiedzi dotyczących prawa może stać się teologia, dla której prawo nie przedstawiało do tej pory żadnego znaczenia. Wraz z Deklaracją z Barmen nastąpiła radykalna zmiana w protestanckim myśleniu o prawie, która przyjęła z biegiem czasu nazwę Teologii prawa. Sytuacja, która wymusiła nową drogę myślenia o prawie w ramach protestantyzmu nie miała swojego źródła wewnątrz Kościoła protestanckiego, lecz została sprowokowana zewnętrznymi warunkami. Jej konsekwencją była schizma, która pojawiła się wewnątrz niemieckiego Kościoła, a która tym samym wzmogła i wymusiła konieczność jej samousprawiedliwienia, ale tym razem $\mathrm{z}$ teologicznego punktu widzenia. ${ }^{11}$

${ }^{11}$ Por. P. GHerII, Primi appunti per una storia delle origini della Teologia del Diritto (canonico), s. 229. 
Obrona słusznej autonomii Kościoła wyznaniowego, a tym samym prawdziwego Kościoła, tak w zakresie organizacyjnym jak i funkcjonalnym wobec państwa, które przyjęło postawy całkowicie przeciwstawne ewangelicznemu duchowi wymusiła zupełnie nowe, dotychczas nieobecne, zainteresowania dla teologii protestanckiej. Przedmiotem teologicznych aspiracji musiało stać się prawo. Nie miało to być jednak prawo samo w sobie, ale jeśli Kościół protestancki miał pozostać wierny swojej tradycji dotyczącej obecności i roli w nim prawa, należało zainteresować się prawem w taki sposób, by mogło ono pełnić należytą i właściwą mu rolę w ramach organizacji kościelnej. Należało przywrócić prawu jego również ewangeliczne znaczenie w taki sposób, by mogło odnosić się do spraw, które są regulowane wewnątrz wspólnoty Kościoła. ${ }^{12}$

Protestancka teologia okresu przedwojennego była jednak silnie naznaczona filozoficznymi wpływami Kanta, Schleiermachera, Hegla czy Straussa, których myślenie oddziaływało również na życie kościelne ówczesnych Niemiec. Teologia liberalna A. Ritschla czy A. von Harnacka (K. Barth był jego uczniem w Berlinie ${ }^{13}$ ) była ściśle powiązana z nowoczesną kulturą niemiecką, wychodząc naprzeciw politycznym i etycznym wyznacznikom epoki. Punktem wyjścia teologicznych rozważań i zrozumienia samego chrześcijaństwa nie było Objawienie, lecz człowiek i jego rzeczywistość. Teologia była podporządkowana rozważaniom dotyczącym wolnego człowieka. Zbliżenie się teologii do nowoczesnej i naukowej kultury poskutkowało jej zredukowaniem do ideologii teologicznej, a tym samym do oddalenia się od faktycznych analiz i zrozumienia tworzącej się rzeczywistości. W tym kontekście Kościół wyznaniowy w Niemczech musiał poszukiwać nowych ujęć teologicznych, które wyraźnie wskazywałyby na całkowitą niemożność połączenia wiary chrześcijańskiej z ideologią nazistowską.

\footnotetext{
${ }^{12}$ Por. tamże, s. 230.

${ }^{13}$ Por. W. Dymny, Barth Karl, w: Encyklopedia Katolicka, Lublin 1989, t. 2, kol. 69.
} 
Teologia liberalna została oskarżona o porzucenie podstawowych zasad wiary czy nawet samego Boga. ${ }^{14}$

Konsekwencje II wojny światowej ukazały jednoznacznie nieadekwatność teologii politycznej, która była przede wszystkim metafizyką państwa, do sytuacji państwowej ukształtowanej po wojnie. Idealistyczno-romantyczne podstawy państwa zostały obalone podczas wojny. Rodzi się nowe podejście teologiczne w Niemczech, którego twórcami nie są filozofowie w świeckim środowisku, lecz teologowie w nurcie Kościoła wyznaniowego. ${ }^{15}$ Nowa teologia w zupełnie inny sposób podchodziła do rzeczywistości tego świata, gdzie punktem wyjścia jej zrozumienia było Objawienie oraz chrystocentryczne ukierunkowanie rzeczywistości stworzonej. J. Moltmann nazywał ją teologią rzeczywistości ziemskich (stworzonych) czy teologią nadziei lub teologią świata. W tych sformułowaniach można dostrzec wyraźnie kształtujące się nowe podejście w teologii niemieckiej, która wychodzi poza obręb państwa niemieckiego i wyzwala się spod usług państwu, a wkracza w szeroki zakres rzeczywistości świata stworzonego przez Boga. Tym samym problem prawa wykracza poza prawo państwowe. Jest on usytuowany w szerokiej perspektywie świata i społeczności ludzkiej. W ten sposób otwiera się nowa perspektywa dla kwestii prawa, którego problematyka staje się przedmiotem zainteresowań teologów. ${ }^{16}$ Teologiczne zainteresowania prawem zmierzały ku poszukiwaniu, wykraczających poza rozważania filozoficzne, jego fundamentów. Chodziło o takie podstawy prawa, które będą całkowicie niezależne od stanowiących prawo sił politycznych, które jednocześnie i jednoznacznie będą gwarantowały poczucie sprawiedliwości i bezpieczeństwa.

${ }^{14}$ Por. P. GHerII, Primi appunti per una storia delle origini della Teologia del Diritto (canonico), s. 236.

${ }^{15}$ Niemiecki Kościół Wyznaniowy faktycznie przestał działać w 1945 r. Nowo ukonstytuowany w 1945 r. Ewangelicki Kościół w Niemczech (Evangelische Kirche in Deutschland) stał się nowym ośrodkiem myśli teologicznej, który zajmował się rozliczeniem z nazistowską przeszłością i kwestią współodpowiedzialności niemieckich chrześcijan. Por. Z. ZIELIŃSKI, Bekennende Kirche, koll. 188-189.

${ }^{16}$ Por. P. GHerII, Primi appunti per una storia delle origini della Teologia del Diritto (canonico), s. 237. 
Ponadto poszukiwanie nowych fundamentów prawa powinno było uniezależnić się od doktryn prawnonaturalnych, których znaczenie dla zrozumienia podstaw prawa, jak pokazały to wypadki II wojny światowej, było znikome czy niedostrzegalne.

Kolejnym impulsem dla podjęcia refleksji teologicznej nad prawem były postanowienia Konstytucji Bońskiej z 1949 r., zgodnie z którą państwo rezygnowało $\mathrm{z}$ ingerencji prawodawczej $\mathrm{w}$ odniesieniu do wyznań protestanckich, przekazując je im samym. Kościoły protestanckie zmuszone były dokonać refleksji nad prawem i jego miejscem oraz roli w strukturach kościelnych. Sytuacja ta wymusiła na teologii protestanckiej konieczność teologicznego uzasadnienia roli prawa wewnątrz Kościoła, tym samym przezwyciężając istniejące od czasów M. Lutra przeciwstawieństwo pomiędzy prawem a ewangelią. ${ }^{17}$

\section{Protestancka teologia prawa}

Teologia protestancka, ujmując prawo jako przedmiot swoich rozważań, stanęła wobec dylematu wartości samego prawa jak również wobec wspomnianego powyżej przeciwstawieństwa. Musiała zatem zmierzyć się z problemem samego prawa, a także prawa w Kościele.

M. Luter dający podstawy dla wyznania protestanckiego, w nawiązaniu do Augustyna i jego podziału na civitas Dei i civitas terrena, ukazuje nowy porządek rzeczywistości. Teologia usprawiedliwienia Lutra, wsparta średniowiecznym woluntaryzmem (Szkot, Ockham) oraz subiektywizmem G. Biela sprawiają, że Luter dochodzi do wniosku, iż prawo Boże jest związane jedynie z życiem religijnym człowieka, a prawo ludzkie dotyczy jedynie wymiaru jego życia naturalnego. Zgodnie ze swoją teorią dwóch królestw (duchowego i czasowego) rozważa istniejące w nich prawo. W królestwie duchowym istnieje prawo duchowe, prawo miłości, prawo Chrystusa, skierowane do człowieka wewnętrznego, które jest ujmowane przez wiarę (prawo wiary). Jest to prawo na wskroś duchowe, które nie nakłada obowiązkowych zachowań zewnętrznych, lecz wymaga wewnętrznej przemiany. $Z$ tej wewnętrznej przemiany wy-

${ }^{17}$ Por. C. M. Redaelli, Il concetto di Diritto della Chiesa nella riflessione canonistica tra Concilio e Codice, Milano 1991, s. 72. 
nikają zewnętrzne zachowania. Natomiast królestwo czasowe opiera się na prawie i władzy, zwraca się do zewnętrznej strony człowieka i wymaga jedynie odpowiedniego zachowania się na zewnątrz. Prawo panujące w tym królestwie jest jedynie złudnym cieniem prawa Bożego, czyli nieodwołalnie niezdolnym do pokonania egoizmu. Reguluje ono życie ograniczone czasowo ustanawiając dyscyplinę dotyczącą materialnej formy życia społecznego. Na mocy posiadanej władzy prawo to może być tworzone jedynie przez państwo. ${ }^{18}$

Teologia M. Lutra a wraz z nią teologia protestancka nie potępia prawa jako takiego. Jest ono rzeczywistością tego świata i jako takie posiada swoje uzasadnienie w odpowiadającym sobie porządku. Zostało ono dane człowiekowi wraz z królestwem czasowym, stworzonym przez Boga po grzechu pierworodnym po to, by ludzkość nie pogłębiała się w chaosie jako konsekwencji grzechu. Prawo ludzkie uczestniczy zatem w Boskim planie uporządkowania zachowań ludzkich. Nie ma ono jednak żadnego znaczenia dla zbawienia człowieka, które jest w stanie zapewnić jedynie sama wiara. Chrześcijańska sprawiedliwość polega na podporządkowaniu się woli Boga. Stąd też dla Lutra prawo Kościoła, ustanawiane przez państwo celem regulacji zachowań ludzkich, również nie posiada znaczenia dla zbawienia. ${ }^{19}$

Protestantyzm wypracował również własną doktrynę prawa naturalnego, która różni się od katolickiej. Odróżnia prawo naturalne duchowe i świeckie. Duchowe (boskie) prawo naturalne jest prawną wolą Boga, który rządzi i osądza na końcu świata. Człowiek nie może osiągnąć tej woli za pomocą własnego rozumu. Bóg jednak może dosięgnąć człowieka dzięki swej woli i swojemu prawu. Świeckie prawo naturalne jest natomiast produktem rozumu, naznaczone logiką i sprawiedliwością. Dekalog i prawo mojżeszowe nie należą do boskiego prawa naturalnego, gdyż są jedynie antropomorficznym obrazem boskiej sprawiedliwości. ${ }^{20}$

${ }^{18}$ Por. L. Gerosa, Teologia del diritto canonico: fondamenti storici e sviluppi sistematici, Lugano-Varese 2005, ss. 61-65.

${ }^{19}$ Por. tamże, s. 65-67.

${ }^{20}$ Por. tamże, s. 64-65. 
Protestancka doktryna dotycząca prawa nie jest doktryną antyprawną Można jednak pokusić się o stwierdzenie, że jest doktryną antyprawnonaturalną. Takie ujęcie zawdzięcza również doktrynie katolickiej, która utożsamia ogólne pojęcie prawa w protestantyzmie z tym, co mieści się $\mathrm{w}$ pojęciu lex moralis naturalis. Jeśli natomiast pod pojęciem prawa, zgodnie $\mathrm{z}$ nauczaniem Lutra, będziemy rozumieli Boży nakaz, który, inaczej niż w średniowieczu nie jest ad nos, lecz in nobis, skierowany do serca człowieka, możliwe jest ujęcie prawa jako przekazu Bożej łaski (Recht der Gnade). ${ }^{21}$ Tylko to prawo, które jest prawem łaski posiada autentyczne znaczenie dla zbawienia człowieka. W Kościele jest to prawo liturgiczne i wyznaniowe, poprzez które wyraża się wiara i które obecne jest we wspólnocie, istniejącej i identyfikującej się wokół samego Chrystusa i tylko dzięki niemu.

Duże znaczenie dla teologii prawa posiadają rozważania K. Bartha. Proponuje on na nowo podjąć tematykę dotyczącą samego prawa. Odwraca luterańskie prawo-ewangelia i ukierunkowuje swoje rozważania wychodząc od związku ewangelia-prawo. Wskazuje tym samym metodologiczne podejście do problemu prawa. Wychodzi od ewangelii i w jej świetle odczytuje każde prawo, nie tylko kościelne.

Tematykę prawa podejmuje w oparciu o zależność istniejącą pomiędzy usprawiedliwieniem i łaską. Odrzuca dualistyczną wizję świata w postaci dwóch królestw (Luter) na rzecz wizji jednorodnej, w której Kościół i państwo wraz ze swoimi porządkami prawnymi istnieją w ramach jednej rzeczywistości zbawczej w Chrystusie.

U podstaw tego przekonania znajduje się centralny problem teologii Bartha, czyli ustalenie natury relacji człowieka do Boga, gdzie punktem wyjścia nie może być teologia naturalna, lecz stwierdzenie, że Bóg jest Bogiem jeśli umiejscawia człowieka wobec jego własnych ograniczeń. Teologia i prawo naturalne nie są w stanie dać człowiekowi w tym momencie żadnych rozwiązań. Jedynie Objawienie może

${ }^{21}$ Por. W. Lienemann, Ius divinum bei Hans Dombois, Zeitschrift für evangelisches Kirchenrecht 32(1987), ss. 423-435; F. D’Agostino, Il diritto come problema teologico, w: tenże, Il diritto come problema teologico ed altri saggi di filosofia e teologia del diritto, Torino 1995, s. 19. 
dać odpowiednie i wiążące rozwiązania. Wprowadza zatem, paralelnie do koncepcji stworzenia, grzechu pierworodnego, pojednania, kategorię usprawiedliwienia, która wyjaśnia naturę relacji Boga do chrześcijanina, ale także Boga do każdego człowieka. Usprawiedliwienie dokonuje się poprzez Chrystusa, który jest ontyczną zasadą całego stworzenia. Jest również jego zasadą epistemologiczną. Rzeczywistość świata może być zatem poznana nie dzięki filozofii, lecz tylko poprzez wiarę. Cała zatem rzeczywistość (Kościół, państwo, prawo, które reguluje stosunki międzyludzkie) może być zrozumiana i poznana jedynie wewnątrz relacji usprawiedliwienia ustanowionej przez Boga (decyzja łaski Boga i decyzja wiary człowieka).

Rezygnując z teorii dwóch królestw i dwóch Kościołów mówi o jednym Królestwie Bożym, w którego centrum znajduje się Chrystus. Wokół Niego koncentruje się cała rzeczywistość (wewnątrz Kościół, na zewnątrz państwo). Nie istnieje zatem absolutna różnica pomiędzy Kościołem i państwem. Kościół ma swoje źródło w prawie Bożym, państwo w prawie naturalnym.

Barth nie widzi zatem miejsca dla prawa naturalnego w eklezjologii. Pierwszym podmiotem działającym w Kościele nie jest wspólnota, lecz Chrystus. Wspólnota nie tworzy prawa i nie jest prawem dla samej siebie, lecz prawo powinno formować się w posłuszeństwie Chrystusowi. Prawo kościelne różni się od państwowego tym, że nie ma formalnej mocy wiążącej tak jak każde prawo, lecz stanowi pewien porządek, który nieustannie jest reformowany. Porządek prawny państwa nie jest w stanie nadać Kościołowi organizacji prawnej, gdyż w sytuacji jednego Królestwa znajduje się od Chrystusa dalej niż Kościół.

Prawo kanoniczne, jak każde prawo, jest prawem ludzkim, obowiązuje tylko w czasie, który oddziela Kościół od eschatologii. W stosunku do prawa państwowego jest prawem sui generis, gdyż jest prawem liturgicznym, uzależnionym od biblijnych wskazań, mającym swoją wartość „w służbie” communio sanctorum (świętych obcowania) i jako proroctwo wobec prawa świeckiego.

Odwracając porządek prawo-ewangelia na ewangelia-prawo podkreśla, że prawo nie sprzeciwia się ewangelii, lecz wspólnie stanowią 
jedność. Prawo i ewangelia są ekspresją słowa Bożego i łaski. Opozycja między prawem i ewangelią może zaistnieć jedynie wtedy, gdy prawo będzie mylnie rozumiane. Prawo jest zatem konieczną formą ewangelii. Prawo kanoniczne wchodzi zatem w treść wiary (Augustyn, Tomasz - nova lex evangelii).

Niestety, w ostateczności nie udało mu się stworzyć jednorodnej wizji prawa Bożego i stanowionego, gdyż nie udało mu się stworzyć i wyjaśnić zależności pomiędzy naturą i nadprzyrodzonością, rozumem i wiarą. Między nimi istnieje nieprzekraczalne przeciwstawieństwo, które rzutuje także na instytucje kościelne.

Cechą charakterystyczną protestanckiej teologii prawa jest odpowiedź na pytanie dotycząc podstaw samego prawa, w tym również prawa Kościoła, z którym protestantyzm musiał sobie poradzić, gdy został zmuszony przejąć dotychczasową rolę państwa w sprawach kościelnych. ${ }^{22}$ Cechą charakterystyczną protestanckiej teologii prawa w poszukiwaniu jego podstaw jest chrystocentryczne ukierunkowanie doświadczenia prawnego. Tym samym otworzyła ona drogę dla teologii kerygmatycznej (cała teologia powinna służyć podstawowej misji Kościoła, czyli zwiastowaniu Chrystusa i Jego Ewangelii ${ }^{23}$ ), podejrzliwej wobec wszelkich uzasadnień filozoficznych.

\section{Katolicka teologia prawa}

Niewątpliwie problemy, jakie wyrosły w obszarze Kościołów protestanckich, wzbudzonych przez wypadki II wojny światowej, przyczyniły się w znacznej mierze do zainspirowania problematyką teologiczną prawa na gruncie katolickim. Jednak problematyka teologiczno-prawna stała się w głównej mierze domeną kanonistów, a nie teologów. Począwszy od powojennych prac K. Mörsdorfa, zainspirowanego poszukiwaniem fundamentów prawa w Kościołach protestanckich, obserwujemy coraz silniejsze zainteresowanie problematyką dotyczącą ontologicznych podstaw prawa w Kościele katolickim.

${ }^{22}$ Protestanckie sposoby uzasadnienia prawa w Kościele (J. Henkel, E. Wolff, H. Dombois) pozostają poza zakresem objętym tematem niniejszego opracowania.

${ }^{23}$ Por. S. C. NAPIÓRKowsKi, Jak uprawiać teologię, Wrocław 2002, ss. 48-49. 
Zainteresowanie tą problematyką, głównie przez kanonistów, przyczyniło się jednak do tego, że katolicka teologia prawa nastawiona była głównie na poszukiwanie w teologii podstaw prawa nie jako takiego, jak to było w punkcie wyjścia teologii protestanckiej, lecz skupiła się wokół fundamentów prawa kanonicznego. Konsekwencją tego było to, że teologia prawa na gruncie katolickim przekształciła się w teologię prawa kanonicznego.

Katolicka teologia prawa, jak zauważa F. D’Agostino, jako refleksja teologiczna dotycząca prawa, a przy tym całkowicie niezależna od dotychczasowej refleksji dotyczącej prawa naturalnego (w tym lex naturalis moralis) jest rzeczywistością od niedawna próbującą przebić się do powszechnej świadomości. ${ }^{24}$ Przedmiotem tej refleksji, wzbudzonej również przez dostrzeżenie nieadekwatności rozwiązań prawnych do życia społecznego proponowanych przez nowoczesne i współczesne kierunki prawa takie jak normatywizm czy pozytywizm, nie są problemy związane z moralnym aspektem normatywności, lecz problemy dotyczące wymiaru ontologicznego prawa, czyli te, które dotyczą intersubiektywnej, społecznej struktury zobowiązującej egzystencji człowieka. W tak pojętej teologii prawa punktem odniesienia dla rozważań teologicznych będą, używając słów S. Cotta ${ }^{25}$, podstawy ontofenomenologiczne prawa sięgające fundamentów ontologicznych ludzkiej egzystencji, które mogą być następnie odczytane w świetle refleksji teologicznej. W przeciwnym razie, jeśli teologia będzie zajmowała się jedynie aspektem moralnym prawa w odniesieniu do założeń i podstaw prawa naturalnego bardzo łatwo i szybko może przybrać charakter wiedzy filozoficznej tworząc filozofię (chrześcijańską?, katolicką?) prawa.

Teologia katolicka, inaczej niż teologia protestancka, uznając wartość rzeczywistości ziemskich dla zbawienia powinna zatem dostrzegać prawo jako zobowiązujący wymiar ludzkiej egzystencji społecznej, mający swoją wartość na drodze człowieka dążącego do zbawienia.

\footnotetext{
${ }^{24}$ F. D'A Agostino, Il diritto come problema teologico, s. 15.

${ }^{25}$ Por. S. CotTA, Il diritto nell 'esistenza. Linee di ontofenomenologia giuridica, Milano 1991.
} 
Przypomniał o tym Sobór Watykański II stwierdzając, że „wszystkie rzeczy bowiem z samego faktu, że są stworzone, mają własną trwałość, prawdziwość, dobroć i równocześnie własne prawa i porządek, które człowiek winien uszanować, uznawszy właściwe metody poszczególnych nauk czy sztuk" ${ }^{26}$ Właściwe i autentyczne ujęcie rzeczy tego świata implikuje ich otwarcie na wiarę, „sprawy bowiem świeckie i sprawy wiary wywodzą swój początek od tego samego Boga". ${ }^{27}$ $\mathrm{Z}$ drugiej zaś strony jakieś, nawet niezbyt do końca świadome, otwarcie na wiarę będzie umożliwiało również coraz większe zrozumienie i ujęcie rzeczy tworzonych przez człowieka i dla człowieka. Z perspektywy teologicznej próba rozumienia rzeczywistości tego świata bez odwołania się do wiary nie będzie w pełni możliwa, czy też nawet może stać się niemożliwa. W takim podejściu teologicznym nie chodzi jednak o pewną sakralizację rzeczy tego świata (tam mamy np. w protestanckiej teologii K. Bartha), lecz jedynie o zrozumienie wartości rzeczy w świetle intelektualnych impulsów pochodzących z poznania teologicznego, dając im tym samym szersze i głębsze znaczenie, ukryte przed możliwościami poznawczymi naturalnego rozumu. ${ }^{28}$ Chodzi zatem o poznanie zobowiązujących i społecznych form życia, zwanych prawem, poprzez rozum oświecony wiarą.

Katolicka teologia prawa nie jest zatem dyscypliną, która w punkcie wyjścia będzie narzucała własne rozwiązania, mówiąc chociażby o „chrześcijańskim” czy „katolickim” prawie. Punktem wyjścia teologicznych rozważań jest samo prawo, jako wartość, która kształtuje i wyraża zobowiązujące wymiary stosunków międzyosobowych. Tym stosunkom międzyosobowym teologia może nadać jedynie nową lekturę, stając się hermeneutycznym punktem odniesienia dla rozumowych rozwiązań. Teologiczna lektura prawa może zatem zaoferować naukom prawnym nową wizję podstawowych koncepcji prawnych: system prawny może otworzyć się na doświadczenie prawne, małżeń-

\footnotetext{
${ }^{26} \mathrm{KDK} 36.2$.

${ }^{27}$ Tamże.

${ }^{28}$ Por. F. D’Agostino, Il diritto come problema teologico, s. 24.
} 
stwo ujmowane jako kontrakt na małżeńskie przymierze ${ }^{29}$, poczytalność na odpowiedzialność, stosowanie procedur prawnych na administrowanie sprawiedliwości, podmiot prawa na osobę ludzką. ${ }^{30}$

Odczytywanie ontofenomenologicznych podstaw prawa w świetle poznania teologicznego pozwala na uchwycenie różnic pomiędzy ujęciem czysto rozumowym, a rozumem oświeconym wiarą. Porządki prawne zachodniej kultury prawa jak i teologia odwołują się tak chętnie do godności człowieka. Godność ludzka w ujęciu świeckim oparta jest na rozumie, wolnej woli i sumieniu, czemu został dany wyraz w Powszechnej Deklaracji Praw Człowieka z 1948 r. Godność w ujęciu chrześcijańskim opiera się przede wszystkim na stworzeniu człowieka na obraz i podobieństwo Boże, aby w ten sposób dzięki łasce osiągnął podobieństwo do Boga. Objawiony Bóg chrześcijan to Bóg dialogu, Bóg osobowy, Bóg zdolny do poświęceń dla każdego człowieka. Objawiona koncepcja Boga tworzy koncepcję człowieka, osoby, która jest nowością w stosunku do rzymskiej koncepcji osoby, ujmowanej jako czysta zewnętrzność, przez co do jej opisywania używano pojęć zaczerpniętych ze sztuk teatralnych. Chrześcijaństwo mówiąc o osobie, odwołuje się do osób Boskich będących nieustannie w relacjach między sobą i zapraszających człowieka do udziału w tejże wspólnocie. Osoba, to ktoś, kto żyje we wspólnocie na obraz życia wspólnoty osób ludzkich. Taki obraz osoby będzie uzupełniał obraz osoby, która jest podmiotem prawa. Teologia kerygmatyczna będzie zatem miała wiele do powiedzenia w przedmiocie ustalania stosunków międzyludzkich, zwracając uwagę na to kim jest ten, który jest podmiotem prawa. ${ }^{31} \mathrm{~A}$ jest nim człowiek stworzony na obraz i podobieństwo Boga, posiadający własną i nieredukowalną godność osobową, nadającą mu wewnętrzny sens jego życia, jego wymiar niejako

\footnotetext{
${ }^{29}$ Por. T. GaŁkowski, Instytucja małżeństwa $w$ świetle instytucjonalnej koncepcji Kościoła II Soboru Watykańskiego, Łódzkie Studia Teologiczne 20 (2011), ss. 89-102.

${ }^{30}$ Por. F. D’Agostino, La teologia del diritto alla prova del fondamentalismo, w: tenże (a cura di), Ius divinum. Fondamentalismo religioso ed esperienza giuridica, Torino 1998, ss. 119-120.

${ }^{31}$ Por. T. GaŁkowski, Od czlowieka, osoby, podmiotu do podmiotu prawa, RNP KUL 18(2008) 2, ss. 7-41.
} 
sakralny, nienaruszalny. Jest nim człowiek stworzony w Adamie, członek wielkiej rodziny ludzkiej, w której braterska równość wszystkich osób nie może ustąpić przed żadnymi formami podkreślającymi różnice wskazujące na podporządkowanie, a życie społeczne oparte jest na wartościach solidarności i współczucia. Jest nim człowiek obdarzony rozumem, dzięki któremu może on poznawać prawdę zgodnie z własnym sumieniem..$^{32}$ „Porządek zatem społeczny i jego rozwój winien być nastawiony nieustannie na dobro osób, ponieważ od ich porządku winien być uzależniony porządek rzeczy, a nie na odwrót". ${ }^{33}$

Chrześcijańska refleksja teologiczna dotyczącą osoby miała swój znaczący udział w powstaniu idei praw człowieka. Idea praw człowieka ujmowana jest jednak w odmienny sposób przez protestancką i katolicką teologię prawa. Ta pierwsza, choć z sympatią ocenia ich wartość, to jednak nie dostrzega takiej dla zbawienia. Pozostaje w mocy stwierdzenie M. Lutra w odniesieniu do wartości prawa: cierpienie, cierpienie, krzyż, krzyż: to jest prawo chrześcijan, to i nie żadne inne. ${ }^{34}$ Dla katolickiej teologii prawa, prawa człowieka posiadają wartość również teologiczną. W idei praw człowieka dostrzega ona obronę ludzkiej godności, która posiada, ze względu na stworzenie człowieka na obraz i podobieństwo Boże, wartość transkulturową. Podkreślana w ten sposób wartość praw człowieka zajęła w nauczaniu Magisterium miejsce wcześniej wszechobecnego prawa naturalnego. ${ }^{35}$

Zarówno protestancka jak i katolicka teologia prawa wykazują swoje zainteresowanie prawem. Pomimo tradycyjnego antyjurydycznego podejścia do prawa, które nie posiada znaczenia dla zbawienia człowieka, teologia protestancka dostrzega jednak w prawie i jego odniesieniu do nakazu i woli Boga, skierowanych do serca człowieka $\mathrm{i}$ istniejących in nobis, przekaz Bożej łaski (ius gratiae, ius caritatis). Katolicka teologia prawa, ze względu na dostrzegalną wartość rzeczy stworzonych docenia wartość prawa jako jednego z wielu elementów

${ }^{32}$ Por. F. D'Agostino, La teologia del Diritto positivo: Annunzio Cristiano e Verità del Diritto, s. 125.

${ }^{33}$ KDK 26.3.

${ }^{34}$ M. Lutero, Scritti politici, Torino 1959, s. 457.

${ }^{35}$ Por. F. D’Agostino, Il diritto come problema teologico, s. 20. 
na drodze do zbawienia człowieka. Chrześcijanin odkrywając wartość prawa postępuje zgodnie z nim wzmocniony wiarą wspartą na boskiej sprawiedliwości.

\section{Theology of law}

The beginnings of theology of law should be sought in the Protestant theology during the prevalence of Nazi ideology. On the Catholic ground, the theology of law as it was developed in Protestantism gained the character of theology of the Canon Law or was blurred as part of moral theology in which the reference point for the assessment of law was lex moralis naturalis. Theology of law from the Catholic point of view should abandon deliberations on the moral aspect of the norm and assume as a starting point the categori$\mathrm{cal}$, intersubjective and obligatory relation as an object of research. Therefore, theological-legal interests should focus on the human himself who creates the relation of obligation and fills it with meaning. Telling about the one who is the author of the legal relation in the light of Revelation, theology of law points out the foundations of a legal phenomenon. Thus, theology of law refers to the law itself in the light of Revelation, framing its theological foundations. If the theology of law concentrated solely on the aspect of content of the legal relation (the norm) or wished to favour it in comparison with the interpersonal relation itself, it would make law a static reality, expressed by a human as a certain form of explicit way of existence and activity.

Theology of law plays a vital role on the epistemological plane learning about a human living sub specie iuris. In this respect, theology of law has a tremendous role to play in the cultural and legal context as a specific hermeneutic category in getting familiar with and understanding a legal relation. Theology of law can give law new horizons of its existence and reveal a new sense to it. The objective of theology of law is not filling law with theological content but showing it the realities discovered in a different way of cognition. Theology of law can become a cognitive suggestion and inspiration for the established law. 